September 2008

\title{
Contextual Influences on Parental Involvement in College Going: Variations by Socioeconomic Class
}

Heather T. Rowan-Kenyon

University of Virginia

Angela D. Bell

University of Georgia

Laura W. Perna

University of Pennsylvania, Iperna@gse.upenn.edu

Follow this and additional works at: https://repository.upenn.edu/gse_pubs

\section{Recommended Citation}

Rowan-Kenyon, H. T., Bell, A. D., \& Perna, L. W. (2008). Contextual Influences on Parental Involvement in College Going: Variations by Socioeconomic Class. Retrieved from https://repository.upenn.edu/ gse_pubs/172

Copyright $\odot 2008$ The Ohio State University Press. Reprinted from The Journal of Higher Education, Volume 79, Issue 5, September/October 2008, pages 564-586.

Publisher URL: http://muse.jhu.edu/journals/journal_of_higher_education/

This paper is posted at ScholarlyCommons. https://repository.upenn.edu/gse_pubs/172

For more information, please contact repository@pobox.upenn.edu. 


\title{
Contextual Influences on Parental Involvement in College Going: Variations by Socioeconomic Class
}

\author{
Abstract \\ College enrollment rates vary systematically based on income and socioeconomic status (SES), with \\ lower enrollment rates for lower-income students and students with lower SES than for their higher- \\ income and SES peers (Cabrera \& La Nasa, 2001). Although college enrollment rates increased for all \\ groups over the past three decades, the gap in these rates between students from low-income families \\ and those from high-income families was the same size in 1997 as in 1970 (32 percentage points; \\ Fitzgerald \& Delaney, 2002). Using data from the National Educational Longitudinal Study (NELS), Cabrera \\ and La Nasa (2001) found that, after controlling for relevant variables, college application rates were 26 \\ percentage points lower for students with low socioeconomic status than for those with high \\ socioeconomic status. These differential application and enrollment rates are especially disconcerting at \\ a time when there are widening gaps in income and health insurance benefits between high school and \\ college graduates (Baum \& Ma, 2007).

\section{Comments} \\ Copyright $@ 2008$ The Ohio State University Press. Reprinted from The Journal of Higher Education, \\ Volume 79, Issue 5, September/October 2008, pages 564-586. \\ Publisher URL: http://muse.jhu.edu/journals/journal_of_higher_education/
}




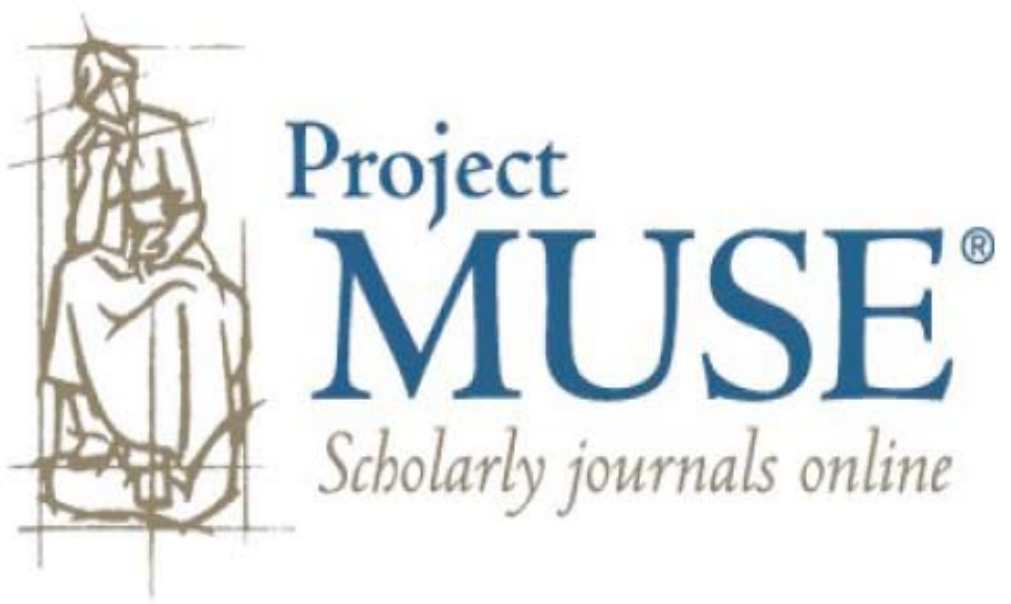




\section{Heather T. Rowan-Kenyon \\ \# Angela D. Bell \\ Laura W. Perna}

\section{Contextual Influences on Parental Involvement in College Going: Variations by Socioeconomic Class}

College enrollment rates vary systematically based on income and socioeconomic status (SES), with lower enrollment rates for lower-income students and students with lower SES than for their higher-income and SES peers (Cabrera \& La Nasa, 2001). Although college enrollment rates increased for all groups over the past three decades, the gap in these rates between students from low-income families and those from high-income families was the same size in 1997 as in 1970 (32 percentage points; Fitzgerald \& Delaney, 2002). Using data from the National Educational Longitudinal Study (NELS), Cabrera and La Nasa (2001) found that, after controlling for relevant variables, college application rates were 26 percentage points lower for students with low socioeconomic status than for those with high socioeconomic status. These differential application and enrollment rates are especially disconcerting at a time when there are widening gaps in income and health insurance benefits between high school and college graduates (Baum \& Ma, 2007).

This research was funded by the Lumina Foundation for Education. The opinions expressed in this paper are those of the authors and do not necessarily represent the views of the Lumina Foundation or its employees. A previous version of this manuscript was presented at the 2007 annual meeting of the American Educational Research Association, Chicago, IL.

Heather T. Rowan-Kenyon is an Assistant Professor in the Department of Leadership, Foundations, and Policy at the University of Virginia. Angela D. Bell is a doctoral candidate in higher education at the University of Georgia. Laura W. Perna is an Associate Professor in the Graduate School of Education at the University of Pennsylvania.

The Journal of Higher Education, Vol. 79, No. 5 (September/October 2008)

Copyright () 2008 by The Ohio State University 
One source of differences across groups in college-related outcomes may be the degree of parental involvement. Research shows that parental involvement is positively related to college aspirations and enrollment (Cabrera \& La Nasa, 2000; Horn, 1998; Hossler, Schmit, \& Vesper, 1999; Perna, 2000), as well as to measures of academic preparation for college (Lee, 1993; Muller, 1993; Zick, Bryant, \& Osterbacka, 2001). But involvement is often limited for low-income parents by economic, social, and psychological barriers (Furstenberg, Cook, Eccles, Elder, \& Sameroff, 1999; Hoover-Dempsey \& Sandler, 1997; Perna, 2004).

Although prior research sheds light on the relationship between parental involvement and college opportunity, as Perna and Titus (2005) argue, research on the contribution of parental involvement to college opportunity is limited in several ways. First, with only a few exceptions, quantitative research typically operationalizes parental involvement using a narrow set of indicators that focus on quantity rather than quality of different types of involvement. Second, while Perna and Titus use multilevel modeling to demonstrate the relationship between both student- and school-level measures of parental involvement and college enrollment, few researchers examine how parental involvement is shaped by school structures and, conversely, how school efforts to promote college opportunity are shaped by parental involvement. Finally, while some research explores racial/ethnic group differences in the relationship between parental involvement and college enrollment (e.g., Perna \& Titus, 2005), little is known about variations in the relationship based on socioeconomic status.

This study addresses these knowledge gaps by drawing on a multilevel model of college enrollment (Perna, 2006) and multiple descriptive case studies of 15 high schools. The study describes how parental involvement not only is shaped by the school context but also shapes the school context for college opportunity. The study also describes the ways other aspects of context, particularly the higher education context and the state and economic context, shape parental involvement. Although parental encouragement and involvement appear to be important facilitators of college enrollment, this study describes the barriers that limit parental involvement not only for low-SES parents but also for middle-SES parents. "Shape" is used throughout this article as a term to describe the multiple ways that aspects of context influence, and are influenced by, parental involvement.

\section{Conceptual Framework}

Based on a review and synthesis of prior research, the conceptual model (Perna, 2006) draws on multiple theoretical perspectives and as- 
sumes that students' college-related decisions are shaped by multiple layers of context. The model assumes that the most important studentlevel predictors of college enrollment are academic preparation and achievement, financial resources, knowledge about college, and family support (Perna, 2006). The model also assumes that college enrollment decisions can be fully understood only by taking into account four layers of context: students and their families, K-12 schools, higher education institutions, and the broader societal, economic, and policy context (Perna, 2006).

Most relevant research focuses on the innermost layer of the model: the relationship between a student's parental encouragement and involvement and the student's college-related outcomes. Based on their review and synthesis of prior research, Cabrera and La Nasa (2000) concluded that parental encouragement may be manifested via high expectations for the students' degree attainment, a motivational form of encouragement, and via particular activities, a proactive form of encouragement. Proactive activities may include parental involvement in school activities and processes, parental saving for college, and parentstudent discussions about college and education-related topics. As Grodsky and Jones (2004) speculate, such activities may reflect parents' level of commitment to their children's educational attainment.

Researchers (Gándara, 2002; Lareau, 1987, 2000; McDonough, 1997; Perna \& Titus, 2005) typically conceptualize parental involvement as a form of social or cultural capital that promotes college enrollment. Coleman (1988) stresses the role of parental involvement in building social capital, arguing that social capital communicates the norms, trust, authority, and social controls that are required for educational attainment. Reflecting Bourdieu's conceptualization, McDonough (1997) shows that students from high-SES families have the most valued forms of social and cultural capital and that they use this capital to maintain their class status. Most obviously, high-SES parents use their knowledge of their own college experience to advance their children's college enrollment processes (McDonough, 1997). Based on their analyses of data from the NELS, Plank and Jordan (2001) concluded that both families and school personnel are important sources of college-related information and guidance. But parents of low and high social classes utilize different sources or social networks to acquire college-related information (Lareau, 1987). Based on her study of parents and teachers of first- and second-grade students, Lareau found that working-class parents generally relied on local extended family for information, whereas middleclass parents tended to rely on parents of other children attending the same school. 
Psychological barriers often limit involvement of low-income and minority parents (Perna, 2004). Based on their review of psychological theory and research, Hoover-Dempsey and Sandler (1997) argued that parental involvement in children's elementary and secondary school education is shaped by parents' role construction, parents' sense of self-efficacy, and parents' perceptions that their children's school invites their involvement. This framework suggests that parents who have not attended college are less likely to participate in college planning activities because they do not perceive such activities to be consistent with their view of appropriate behaviors (i.e., their role construction), because they do not believe that their involvement can have a positive effect on their child's college outcomes (i.e., their self-efficacy), or because they do not believe that the school wants them to be involved.

Reflecting Bourdieu's view that an individual's behaviors are shaped by the social context (Perna \& Titus, 2005), a smaller body of research suggests the importance of considering the school context when examining the contribution of parental involvement to college enrollment. Based on their multilevel analyses of data from the NELS:92/94, Perna and Titus (2005) showed that the probability of enrolling in a two-year or four-year college increases not only with a student's own level of parental involvement but also with the average level of parental involvement at the school. Specifically, even after student-level characteristics and other school-level characteristics are controlled for, the likelihood of enrolling in a four-year college is positively related to such schoollevel measures of parental involvement and support as the frequency of parent-initiated contact with the school about academics, parental education, and parental expectations for their children's education (Perna \& Titus, 2005).

Other research suggests the particular importance of school support for college enrollment for students from low-income and minority families. Gándara (1995) found that Chicano parents who were not familiar with schooling in the United States were not confident about their ability to communicate with personnel at their child's school. Lareau (2000) found that low-income parents often relied on the school to help the student as much as possible since parents often believed that they did not have the skills to do so. Similarly, Lareau's (1987) qualitative examination of parents and teachers of first- and second-grade students shows that, for reasons that include lack of resources (e.g., time, money, job flexibility), absence of knowledge about their child's school experiences, and low levels of formal education, parents at a working-class school generally relied on the teacher to educate their child. In contrast, parents at a middle-class school viewed their child's education as a 
shared and mutually reinforcing process that requires parental involvement in school activities and that occurs both in school and at home. As such, parents in the middle-class school more frequently requested additional educational resources for their children, monitored teacher behavior, and consulted with other parents and teachers about the educational experiences of their child. Furstenberg and colleagues (1999) concluded that because low-income students and their families are not "active consumers" in the educational process, schools need to proactively encourage parents to be engaged in their children's education.

Nonetheless, structural barriers limit the extent to which low-income and minority students and parents receive the necessary information from schools (Perna, 2004). Stanton-Salazar (1997) found that school structures and processes prohibit the development of "trusting" relationships among working-class minority students and "institutional agents" (e.g., teachers, counselors, and middle-class peers). These students are thus at a disadvantage, as institutional agents are a source of resources, opportunities, and information. Among the limiting school structures are the focus of schools on bureaucratic processes, the dual role of teachers and counselors as mentors and gatekeepers, and the short-term duration of interactions (Stanton-Salazar, 1997).

In summary, prior research shows that parental involvement is related to college-related outcomes and that involvement is often constrained for parents with low family income or socioeconomic status. A smaller body of research suggests the contribution of the school context to the relationship between parental involvement and college-related outcomes. Little is known about how other aspects of the context, particularly the higher education context or the broader social, economic, or policy context, also shape the relationship between parental involvement and college-related activities. Little is also known about how parental involvement not only is shaped by the school context but also shapes college-related activities at a school.

\section{Research Method}

This study relies on data from descriptive case studies of 15 high schools, three in each of five states. Case study methodology is appropriate given our interest in understanding how parental involvement shapes college opportunity and how different forces shape this involvement and given our focus on the "contextual conditions" that shape college opportunity (Yin, 2003b).

We chose the five states based on their variation in economic, political, demographic, and educational characteristics. The five states are 
California, Florida, Georgia, Maryland, and Pennsylvania. Most notably for this study, average levels of educational attainment vary across the five states. In 2006, the share of the population aged 25 to 65 with at least a bachelor's degree ranged from $26 \%$ in Georgia, to $28 \%$ in Florida, 30\% in Pennsylvania, 33\% in California, and 37\% in Maryland (National Center for Public Policy and Higher Education, 2006). The five states also vary in terms of their higher education policy context. For example, in Florida and Georgia about two-thirds of all state grant aid is awarded based only on merit, compared with none of the state grant aid awarded in Pennsylvania, $8 \%$ of the grant aid in California, and $6 \%$ of the grant aid in Maryland (NASSGAP, 2005).

To select the 15 high schools, we first created a profile of demographic and academic characteristics for all high schools in each of the five states. Data for this profile were drawn from the U.S. Census Bureau, the Common Core of Data, and each state's department of education. These profiles were then utilized to identify school districts and/or metropolitan areas that had at least three high schools that varied substantially in terms of students' demographic and academic characteristics. Focusing on schools within a single district or metropolitan area helps to control for regional differences in college-related outcomes. Within each school district or metropolitan area, we purposively selected one high school with below-average student achievement and socioeconomic status (low-resource school), one high school with average student achievement and socioeconomic status (middle-resource school), and one with above-average student achievement and socioeconomic status (high-resource school). Using the percentage of adults in the school district who have at least a bachelor's degree as a proxy for parental education suggests substantial variation across the 15 schools in average parental educational attainment. At six of the schools, no more than $20 \%$ of the adult population holds at least a bachelor's degree. At four schools more than $50 \%$ of the adult population holds a bachelor's degree or higher. For additional characteristics of participating schools, please see Perna et al., 2008.

\section{Data Collection and Analyses}

As recommended by Yin (2003a), we developed data collection protocols based on the conceptual framework and a literature review of the predictors of college enrollment. The use of a standard protocol helped ensure that the research team collected comparable data for all schools in the study. Part of a larger study of the influence of federal, state, and local policies that shape college opportunity, the protocol addressed such questions as: What public policies and programs are designed to 
promote college opportunity for students attending this school? What are the perceived and actual college-related outcomes? What are the barriers to college opportunity for students attending this school?

The research team completed the protocols using multiple sources of data, including the demographic and academic school profiles; a review of the federal, state, and local policies in each state; and individual and focus-group interviews. At each school we conducted semistructured interviews with teachers and counselors and focus groups of ninth-grade and eleventh-grade students. Parent focus groups were conducted at all but the Florida low-resource school. Spanish translators were used for two parent focus groups. Each individual and focus-group interview lasted between 45 and 90 minutes and was audio-recorded and transcribed. Between 20 and 58 individuals at each school participated in the study, for a total of 596 participants. Interview and focus-group questions included the following: How do parents promote or impede college opportunity? What can students, parents, counselors, and teachers do to increase the chances that students in this school will attend college?

Following Yin's (2003b) recommendation, we created a case study database that included all transcriptions, as well as data from the policy analyses and demographic and academic profiles. Using the college access literature and the conceptual framework, we developed a list of preliminary codes. We also added codes as they emerged from a review of the transcripts. We utilized HyperResearch to assist with the data coding and analyses.

To ensure the credibility and trustworthiness of the findings and conclusions, we collected data from individuals with diverse viewpoints, including students, parents, and school personnel to ensure construct validity (Yin, 2003b). We also asked the primary school contact to review a draft case study report for that school, correct any misperceptions, and provide other feedback (Yin, 2003b). Reliability was enhanced by involving multiple members of the research team in the coding and analyses of data.

\section{Limitations}

This study has several limitations. First, although the study provides an in-depth understanding of parental involvement and the roles of the school, higher education, and state, economic, and policy contexts in shaping this involvement, the findings are based on data describing only 15 schools. Therefore, the findings of this study are not generalizable to all schools in all states. Second, within each school our sample includes a relatively small number of participants. Moreover, these participants 
are not necessarily representative of the student body as a whole, as the student and parent participants tended to aspire to college. Nonetheless, we use these data as well as data from teacher and counselor interviews and the demographic and academic profiles to draw inferences about class-based differences across schools. Third, by focusing only on the role of parents, the study reflects a traditional view of families with no attention to the role of older siblings, members of the extended family, and other nontraditional family arrangements (Perna, 2004; Tierney, 2002; Tierney \& Auerbach, 2005). Nonetheless, while important to acknowledge, these limitations do not minimize the contribution of this examination of the relationship between parental involvement and college opportunity.

\section{Findings}

Using the conceptual model as a guide, three themes emerge from the data: (a) parents shape college opportunity for their children, but involvement varies based on socioeconomic status; (b) parental involvement is shaped by, and also shapes, the school context for college opportunity; and (c) parental involvement is also shaped by the higher education context and the social, economic, and policy context.

\section{Parents Shape College Opportunity for Their Children, but Involvement Varies}

As suggested in prior research (Cabrera \& La Nasa, 2000; Perna \& Titus, 2005), parents shape college opportunity for their children in a variety of ways. Participants indicate that parents support and encourage college opportunity through their expectations for their children's educational and occupational attainment, discussions with their children about college-related activities, efforts to take their children to visit colleges, and ability and willingness to pay college prices.

At all schools, most parents encourage their children to aspire to college by having high expectations for their children's educational and occupational attainment and by regularly asking their children about their college-related plans and activities. In a representative example, a ninthgrade parent at the low-resource school in Maryland stated, "I put [in] them the idea that they-it's an unfinished business if they don't go and do it [go to college]. And they know already that the study doesn't change when they finish high school. They know they have to go somewhere." 
Reinforcing what is known about the advantages accruing to students whose parents have attended college (e.g., McDonough, 1997), collegeeducated parents in this study send implicit and explicit messages that their child is expected to follow in their footsteps and go on to college. In a representative example, an $11^{\text {th }}$-grader at the Pennsylvania high-resource school shared, "Like our parents, for the most part, they went to college, and it's like we're expected to do it." A student at the Maryland low-resource school stated, "I always wanted to go to college. My parents are always talking to me about the colleges they went to, so I guess that's probably what it is. It's my parents."

Parents who have not attended college are less able to give these same messages to their children. An $11^{\text {th }}$-grade student at the Pennsylvania low-resource school stated that her parents talked to her about college "all the time." But, when asked what they talked about, she said "that I just need to get out of [this town] and it will be better for me in the long run." A student at the California low-resource school stated, "I don't have very much push or involvement at home, so a lot of it relies on my own like willingness to do that [get information about college] and it is just my own kind of push towards it."

The ways in which, and the extent to which, parents expose their children to college also vary based on parents' educational attainment. Many students and parents report that parents take students to visit colleges. A ninth-grader at a Maryland high-resource school said,

Me and my parents, we are taking a trip down to Georgia and then on the way home we are stopping at 10 colleges that I choose and my dad wants me to look at a small, medium, and large college and different types of campuses and different types of colleges, so that I know what type I want to look into more.

In addition to differences by parents' educational attainment, study findings also show variations in involvement based on economics, language, and other characteristics. Consistent with Lareau's (1987) study of first- and second-grade parents and teachers, some parents are more dependent on the school to provide necessary college-related guidance and information. For example, parents at the low-resource California school reported that they encourage their children to enroll in college. But, when asked more specifically how they help their students acquire necessary information, one of the parents responded, "I will say mainly through the high school . . . because I am not familiar with universities and their fields or anything else like major fields, and like what universities have an emphasis in a certain area." 
Parents' financial assistance for college enrollment also varies based on socioeconomic status. In high-resource schools, parents typically stated that they had been saving money for college or that they would find a way to finance their student's education. In the words of an 11th-grade parent from the California high-resource school:

We're looking at every means possible. ... We're encouraging our son to go to a UC, but if he's really got his heart set on private, then we'll just explore every and all possibilities. And, I think, you know, other parents I've talked to feel the same way.

In contrast, consistent with their perception of a "middle-income squeeze" (see economic context below), many middle-income parents indicated that responsibility for paying college costs would be shared with their students. A parent at the Pennsylvania middle-resource school described his "expectation that our children are going to pay, you know, some of the freight for college, or at least some of their living expenses." At the Maryland middle-resource school a parent echoed this notion by saying, "Now my feeling is he will take whatever loans he has to do and some of them we'll pay and some he'll pay."

In a third pattern, parents at the low-resource schools were typically uncertain about how to pay college prices. In the words of a parent at the low-resource school in Maryland,

I really worry about the money. ... And it's daily worry about the money. ... My brother says, "You just have three years left because your son is in ninth grade. And you don't have nothing [saved for college]?" And I said "Well, God will provide."

Only a few parents at the low-resource schools indicated that they had saved some money for their children's postsecondary education. The atypical nature of this saving is described by a parent at the Pennsylvania low-resource school in the following words:

There are people like my husband and I-we started the TAP fund right away. . . .We've got two years of college already paid for. . . . It is a real relief. But most people don't have that extra $\$ 25$ a month to put aside-just the economy of the town.

In summary, perhaps reflecting the fact that they agreed to participate in the study, all participating parents are supportive of their children and encourage higher education. But gaps emerge in the availability of resources (e.g., information, money, and time) for providing more com- 
prehensive support for their students. This lack of resources tends to increase students' and families' reliance on the school for college-related guidance and support.

\section{Parental Involvement Is Shaped by, and Shapes, the School Context for College Opportunity}

All of the schools offer at least a minimal level of outreach to parents, most commonly in the form of college and financial-aid nights as well as newsletters. As an example, the counselor at the California high-resource school stated that the school "holds at least one [parent] meeting a month," publishes a parent newsletter, and twice each year produces and distributes a time line that "basically walks [parents] through dates and deadlines." At schools with a high percentage of immigrant students and parents whose primary language is not English, schools make additional efforts to provide information in Spanish. A counselor at the California low-resource school stated that "everything that goes out is translated. So everything is in English and Spanish."

Parental responses to school efforts to involve parents vary both across and within schools based on school and student SES and achievement. For example, attendance at parent events increases with the average resource level of the school. At the Pennsylvania high-resource school a teacher reported, "The college fairs that they [parents] come in for, and the turnouts for that are standing room only." In contrast, a counselor at the Pennsylvania low-resource school reported that only $10 \%$ of the school's senior parents attended a recent financial-aid night.

Within a school, parental attendance at these events also increases with student achievement. A teacher at the high-resource school in Pennsylvania stated, "I know with the level one, which is the honors level, you get $70 \%$ participation in some form ... and the parents that you do really want to see, you send home a notice and say 'I'd really like to meet with you during these days,' and they don't show up."

At the high-resource schools, school staff state that at least some parents are overly involved in their children's education. In one example, a counselor at the Georgia high-resource school reports that "we'll get a phone call saying, 'This is Mrs. So-and-so, and I'm doing Jill's application right now online,' and you're like, 'Excuse me?'" Moreover, even though high-SES schools offer relatively extensive college counseling and other resources, parents at these schools often hire private counselors and/or pay for private admissions test preparation courses.

School staff and parents mention several barriers that limit parental involvement for low-SES parents. A teacher in the Georgia low-resource school explained that "a lot of parents have a working schedule and it in- 
terferes; even though [the financial-aid information session] is offered late at night, we can't get some parents here that may need that information." Similarly, a counselor at the middle-resource school in California stated,

I would probably say about 50\% [of the parents are focused on survival rather than involvement]. . . We have students who are coming from [a nearby town and] tend to be first-generation college students. And a lot of their parents tend to work in either agriculture field workers or, you know, jobs that don't require, you know, a four-year degree. So those parents are really interested in getting help, but the challenge is they can't take time off from work for a schedule, usually working late so when [there are] the parent nights, they don't, they don't have an opportunity to come out.

The experiences of a few schools suggest the benefits of recognizing the barriers to involvement by adopting alternative approaches to engaging parents. At the high-resource Florida school a counselor created lunchtime workshops, explaining that "I just come into the library for two weeks every lunchtime and the kids can come in or the parents can come in and we can work on financial aid." This adviser also works with parents individually to complete Free Education for Federal Student Aid (FAFSA) forms. However, such activities may not be possible in schools with relatively few counseling resources and high noncollege counseling demands.

Another potentially effective form of nontraditional outreach may be for school personnel not to require parents to come to the school, but to engage parents where they are and when they are available. A parent at the low-resource school in Maryland suggests the need for such efforts, stating, "And we need to reach them. This is like a-community and we don't want to lose them." Similarly, another ninth-grade parent at the low-resource school in Maryland argued,

So the school needs to make a better effort at getting to those people who have that second job; don't have it on a Monday or a Thursday night at 7 o'clock when you know, we're turning around from our 9:00 to 5:00 and going to the second job and not getting off until 10 or 11 o'clock. Have it on a weekend, there are people that you know, Saturdays and Sundays are free and the school needs to know that to be a little bit more flexible to get the majority of those parents out there because what it looks like is that we don't care.

One example of an alternative strategy for engaging parents occurred at the low-resource school in Florida. At this school, the college counselor, on her own time and not as part of her job, facilitates collegegoing programming at a local church. She goes to a church four times a year to hold programs about steps to prepare for college, complete financial-aid forms, and acquire scholarships. A second strategy for reaching parents is to provide information on-line, for parents to access at their convenience. Eleven of the 15 schools post college application 
and financial-aid information for students and parents on the school Web site. The four schools that do not provide information on-line are low- or middle-resource schools.

Parents' efforts to shape the school context for college opportunity also vary based on the school's resource level. Parents at high-resource schools often push school staff to provide college-related supports for their children. At the high-SES school in Maryland parents formed a "guidance advisory committee" that developed and coordinated a program of collegerelated activities for the school's students and parents that included at least one program per grade level each year. A counselor reported that "they even actually have to turn people away at this school on that committee because we have so many people who want to be involved."

Similarly, parents at the high-resource schools often confronted the school to advocate on behalf of their children. One example occurred at the California high-resource school with regard to admission to the gifted and talented (GATE) program. A teacher explained,

The way you're supposed to have qualified for GATE was that you were supposed to have taken this GATE screening test and if your IQ was high enough, you could be GATE qualified. [And] there was some caveat that you could also get in by parent request. So that's where the true spirit of GATE goes out the window. And it's not the parents' fault, it's the system's fault. ... These pushy parents just want their kids in GATE.

In summary, all of the schools provide some type of parent programming. Attendance at these programs varies across and within schools based on the socioeconomic status of the family and the achievement level of the student. Participants attribute low involvement to the overburdened schedules of parents and the reliance of schools on traditional ways of involving parents. While parental involvement is shaped by the school context, parents, especially those at high-resource schools also influence the school context for college opportunity.

Parental Involvement Is Shaped by the Higher Education Context

Several aspects of the higher education context appear to affect parent involvement in the college-going process. First, across schools in all states, the recruitment materials that colleges mail to high school students stimulate conversations between parents and students about a variety of topics related to college enrollment. A student at the low-resource school in Pennsylvania explained the role of these materials, stating, "My mom and dad talk to me about college all the time because I always get the letters and stuff in the mail to tell us about it, and they always bring the subject up. And we get stuff in the mail all the time and that is why we talk about it." 
Characteristics of the state higher education system also shape some parents' views of the college-going process. For example, in four of the five states (California, Florida, Georgia, and Maryland but not Pennsylvania) parents expressed concerns about the accessibility of the state flagship institutions. Parents noted that the selectivity of these institutions has increased over time, and many wondered whether their children would be admitted. A parent in the high-resource school in Maryland implies that, because of the increased competition for admission to the state flagship university, parents must manage their children's college-related activities in order to maximize their children's likelihood of admission:

I know that even encouraging him to be on the crew team-I'm not a crazy person about it. ... I have him involved in community service. I want to beef up that piece of paper, so when it goes to those colleges, it looks as good as it can.

Another characteristic of the state higher education system that shapes parents' views is the relative attractiveness of two-year colleges. Two-year institutions, especially in California and Florida, are marketing themselves as cost-effective gateways to the four-year institutions. At schools in these states, parents exhibited knowledge that articulation agreements and transfer support staff at the two-year institutions facilitate this process. This knowledge is part of their conversations with their children about how to navigate their postsecondary careers. A parent at the Florida high-resource school said:

The other advantage ... of going at [the community college] for two years, especially if you're short on money, is that if you complete that two years it's completely accepted by the Florida schools, so you can go on without any, you know, drop of classes or loss of credit.

Not all parents are knowledgeable about the characteristics of the state higher education system, however. Some parents at low-resource schools, especially immigrants, lack this knowledge. Because many of these parents have not gone to college themselves, "college" is a monolithic concept with no perceived distinctions in rigor or curricular offerings. Consequently, these parents are unable to assist their students in discerning the most appropriate options. A parent at the low-resource school in Maryland confessed:

I mean, for us, like first-generation immigrants, we don't know the system. I mean in our own country, you know, people save, but here there's just so much going on, there's so many choices, so many options, and just to navigate the system - I mean, I wish somebody - because we didn't go to college here and so we're not so familiar about the in and out of the system. 
Working against this trend, however, are programs like Upward Bound and Advancement via Individual Determination (AVID) that bring parents and students to university campuses and provide college and career information. When asked how her children found out about the careers they are interested in and whether they know how much education is needed, a Hispanic parent at the high-resource school in California responded through the translator:

Because right here, there's conferences with the parents and the children in the university. And there they ... put up on the projectors what kind of careers they want to go to.... She says yes because from here they take them to the universities and there they talk and ask questions to the instructors on how long they need, how much time they need to study.

A Hispanic parent at the low-resource school in California who had gone to a campus with her child through an early intervention program expressed through the translator: "It would be good if the parents were allowed to start going on the field trips, and going on the university campus so that they could see it for themselves, and actually it is an awesome experience for them."

A third aspect of the higher education context that plays a role in parental involvement is the geographic proximity of institutions. While proximity plays a role in parent discussions at all SES levels, the draw of closer institutions is strongest at the lower-resource serving schools and especially among Latino and immigrant families. Families knew the most about local community colleges and perceived them as a safe solution to the cultural norms that stress keeping their children, especially females, close to home.

\section{Parental Involvement Is Shaped by the Policy and Economic Context}

With regard to the state policy context, characteristics of the state financial-aid program shaped the nature of parents' college-related discussions with their children. Two of the five states, Florida and Georgia, offer substantial state-level merit-aid scholarship programs. Parents at these high schools almost universally know not only about the existence of these programs but also about the criteria for obtaining these funds. Knowledge of HOPE in Georgia and Bright Futures in Florida is in turn part of parents' discussions with their children about higher education. Parents encourage children to keep up their grades with the explicit purpose of ensuring eligibility for the scholarships. A parent from the Florida high-resource school states, 
You're constantly preaching to your child, "You're shooting for Bright Futures, you're shooting for Bright Futures." I mean, you just keep telling them that "you'll get this much money." ... So that's another thing you kind of brainwash them with. So they're shooting for something.

When asked at what point parents start encouraging children to keep up their grades to earn a HOPE scholarship, a Georgia parent from the middle-resource school replied in jest, "How about third grade?" These conversations convey the expectation that children will go on to college and reinforce the need to acquire the necessary academic preparation.

In contrast, in other states few parents know of the existence of statefunded need-based programs or the criteria for obtaining these funds unless the parents themselves or their older children have used the programs. In particular, parents at the low-resource schools in these states have a vague awareness that funds are available for poor students but lack exact knowledge about specific financial-aid programs. Several parents have described how their lack of knowledge of the net price of college (i.e., sticker price less financial aid) contributes to uncertainty in the college planning process. A parent at the Pennsylvania middleresource school explained:

Seems like you don't know until you apply and get accepted, and then see what the financial offer is, and then you figure out, well, could we swing that or not, and this whole idea that, you know, that financial package gets better, the more children that you have in school, and aren't really understanding quite how that works.

Three of the five states, Florida, Maryland, and Pennsylvania, have a prepaid tuition plan that allows parents to pay in advance the price of tuition and thereby safeguard against future large tuition increases. Obviously, participation in these plans requires the availability of disposable income to deposit in this type of account and therefore increases with socioeconomic status (Olivas, 2003). Participation plays a role in parent interaction with students by concretely communicating an expectation that students go to college and increasing parents' confidence in their ability to pay college prices. In the words of a parent at the high-resource Florida school:

She's actually looking now ... she's looking at a school in Florida, because I've got Florida Prepaid and she's probably going to get Bright Futures, and so it's a double ch-ching. . . . I got the Florida Prepaid so I made sure she could go to school, but everything helps.

Several aspects of the economic context also shape parents' collegerelated interactions with their children. One aspect is the perception of a 
"middle-income squeeze" among parents at the middle-resource schools. Consistent with the recent actions of politicians and the sentiments of public opinion polls (Perna \& Li, 2006), parents at the middleresource schools are especially worried about college affordability. The perception of a middle-income squeeze includes the notion that needbased aid is either unavailable or insufficient to make a substantial difference in college affordability. One parent at the middle-resource school in California complained, "And that makes it very difficult for those of us. ...We're paying taxes, I mean, for everybody else to get their kids' education, but, you know, we're the ones who miss out, you know."

As a result of the perceived inadequacy of their own and public financial resources, many parents, especially at the middle-resource California school, articulate that, for their children, the local community college is the only alternative for the first two years. A parent at the middle-resource school in California lamented:

I told my kids that I'll pay the first year's college and thereafter. ... Well, actually if they stay at a junior college I'll pay for their school ... and helping them once they transfer, a little bit, but they're going to have to get loans. We can't afford it. It's-I don't want to lose my house.

Another aspect of the economy that shapes parental involvement is the nature of local industry. For all three California schools in our study the local economy is agriculturally based and reliant on first-generation immigrant labor. All three California schools responded to this characteristic of the population by conducting academic planning and college information sessions in Spanish as well as English. But the obstacles to parental involvement for this population extend beyond language barriers. Agricultural work in this area requires long hours of physical labor and allows limited flexibility for employees. These long and inflexible hours likely prohibit parents from attending college-going programming at schools. A parent at the California middle-resource school noted:

I was bringing in some kids whose parents were out there in the fields early in the morning, 5:00. There's no sun. They have the big lights and stuff. . . . And they're out there working that early. And when I leave going home, those parents are still out there.... And this is not just our area-I'm talking all of California.

\section{Conclusions and Implications}

The findings from this study improve our understanding of the ways that parental involvement shape college enrollment for different families at different schools in different states. While adding to the body of re- 
search that illustrates the nature of parental involvement, this study also sheds light on the structural barriers that limit involvement for many parents. By considering parental involvement in terms of various layers of context, particularly the school, higher education, and policy and economic context, this study suggests that low levels of parental involvement are not so much attributable to the shortcomings of the parents themselves as they are to structures and policies.

The findings from this study suggest several implications for improving parental involvement. Reflecting our central conclusion that increasing parental involvement requires reframing the issue from individual parents' behaviors to the role of structures, policies, and programs, we offer implications beginning with the outermost layer of context and moving in.

\section{State Policy Context and Economic Context}

Consideration of the state policy context offers insights into one barrier to parental involvement in college preparation and planning: the absence of adequate knowledge and information. Although much research raises questions about the equity implications of state merit-based financial-aid programs (e.g., Heller \& Marin, 2004), this study suggests that state merit-aid programs may be doing a better job than state need-based aid programs in terms of educating parents and students early on about the availability of aid to finance college expenses and the requirements for receiving this aid. Unlike parents in other states, parents in Georgia and Florida are aware of their name-brand state merit-aid programs and use this awareness to stimulate and inform their college-related discussions with their children.

Future research should examine the reasons why awareness of the state merit-aid programs is greater than awareness of state need-based aid programs. As Perna (2004) concluded based on her comprehensive review and synthesis of the limited relevant research, little is known about the ways that particular aspects of student-aid design, operations, and marketing influence students' or parents' awareness and understanding of college prices and financial aid or the implications of this awareness for college-related activities. Thus, future research should consider whether differences are attributable to the relative simplicity of eligibility criteria for merit-based compared with need-based programs, the superior marketing of merit-based over need-based aid programs, or some other differentiating characteristic.

The findings from this study suggest that, at a minimum, knowledge of state merit-aid programs encourages college-related conversations between students and parents around college preparation and planning is- 
sues. Logically, earlier knowledge leads to earlier conversations, leading to more opportunity to acquire the necessary college qualifications. Clearly, the present tendency of college financial-aid offices to "market" student financial-aid programs only when they make a financial-aid award to admitted students (Kane, 1999) assumes a level of knowledge and sophistication regarding the availability of financial aid that is not present in all populations. The findings from this study suggest the value of efforts by the Advisory Committee on Student Financial Assistance (2005) and other entities to improve early knowledge of financial aid. The Advisory Committee's report offered 10 recommendations to Congress designed to reduce the complexity of federal student financial-aid application and eligibility requirements such as creating a system of early financial-aid information, allowing students to apply for aid earlier and simplifying the FAFSA on the Web. Implementation of these recommendations will be a powerful step toward improving financial-aid knowledge.

Considering the economic context suggests structural barriers to the involvement of many parents, especially parents with low levels of educational attainment and low occupational status. In California, the challenges that agricultural work creates for traditional types of parental involvement are not idiosyncratic or unique but are a reality for a whole class of workers. Although these findings suggest the challenges facing the least enfranchised parents, future research should more explicitly explore the voices of these parents and their students.

Future research should also explore the ways that the policy and economic context of other states influences parental involvement in children's college-related activities. Although the five states in this study represent a range of state policy and economic contexts for college opportunity, the five states are obviously still only a subset of the 50 states. In particular, future research should focus on states with lower levels of educational attainment in the population and less generous state financial-aid programs.

\section{Higher Education Context}

As predicted by Perna (2006), the findings from this study show that parental involvement in college-related activities is shaped by such aspects of the higher education context as institutional marketing, location, and selectivity. Attention to the interaction between characteristics of the higher education context and parental involvement suggests several potential fruitful areas of intervention.

First, direct-mail college marketing and recruitment materials play a role in parents' college-related discussions with their children. This finding begs questions of who receives college recruitment materials, when, 
and from which institutions. As mailings are typically triggered by students' taking the PSAT, efforts to encourage students to take the test are likely worthwhile. Georgia offers a potential model for other states, as it funds the costs of taking this test for all sophomores in the state. Further research is required to understand variations in the impact of different types of recruitment materials on different types of conversations among parents with different characteristics.

Second, the findings suggest the value of efforts to improve parents' knowledge of the full range of postsecondary educational options that are available. All parents would likely benefit from such efforts. Greater knowledge of the range of postsecondary educational options may help reduce the anxiety high-SES parents feel with regard to the perceived increased selectivity of the state flagship institution and may help inform low-SES parents about alternatives beyond those located in the immediate community.

\section{School Context}

Like other research (Lareau, 1987, 2000; Perna \& Titus, 2005), our findings show that educators have clear expectations about what parents should do to support their children's academic success, particularly in terms of attendance at school-related events. Nonetheless, many parents do not meet these expectations owing to "invisible walls" (Stout, 1996) associated with work commitments, lack of comfort with school staff, language barriers, and conditioned mistrust. If the ultimate goal is having students continue their education beyond high school, school staff must leave behind their preconceptions about what parents should be doing and try new approaches to getting parents involved. Building on the findings from this study and the work of Hoover-Dempsey and Sandler (1997), future research should further explore the psychological dimensions of parental involvement, as well as effective ways for schools to address these dimensions. In particular, as suggested by one insightful reviewer, future research should explore the ways that parents' past childhood school experiences may influence their current involvement in their children's education.

The findings from this study suggest the potential benefits of developing innovative approaches for actively engaging all parents, not just the easy-to-reach parents, in postsecondary educational planning and preparation, but additional work is needed. Little research examines the effectiveness of particular outreach strategies in general, let alone the effectiveness of community-based efforts to improve college enrollment (Perna, 2006). Technology may offer an avenue for reaching parents, but use of Web sites must also recognize differential access to and knowl- 
edge of computers and the Internet (Warschauer, 2004), as well the provision of information to non-English-speaking parents.

The pervasive lack of parental participation in school events among lower-SES parents requires a fundamental rethinking about when, where, and how primary and secondary schools seek to involve the parents of their students. Common sense suggests that taking college-going programming to the community through other organizations such as churches can be effective. Also, as counselors at several of the low-resource schools report that parental involvement is higher at school sporting events, there is potential to use these gatherings to reach more parents. Future research should examine the benefits and costs of such approaches.

\section{Concluding Note}

This study illustrates that schools, higher education institutions, economic forces, and state policies contribute to differences in parental involvement. While not absolving parents of their responsibility to participate actively in their children's education, this study shows that schools, higher education institutions, and public policies are relevant and productive points of intervention. The results of this study reflect a shift from "fixing" parents to ensuring that policies and programs empower parents to be involved to shape their children's educational futures. If structures and systems are created that meet parents where they are geographically, culturally, and in terms of their unique needs, parents of all walks of life will be partners in the college-going process.

\section{References}

Advisory Committee on Student Financial Assistance (2005). The student aid gauntlet: Making access to college simple and certain. Final report of the Special Study of Simplification of Need Analysis and Application for Title IV Aid. Washington, DC: Author.

Baum, S., \& Ma, J. (2007). Education pays 2007: The benefits of higher education for individuals and society. Washington, DC: College Board.

Cabrera, A. F., \& La Nasa, S. M. (2000). Overcoming the tasks on the path to college for America's disadvantaged. In A. F. Cabrera \& S. M. La Nasa (Eds.), Understanding the college choice of disadvantaged students (pp. 33-44). San Francisco: Jossey-Bass.

Cabrera, A. F., \& La Nasa, S. M. (2001). On the path to college: Three critical tasks facing America's disadvantaged. Research in Higher Education, 42, 119-149.

Coleman, J. S. (1988). Social capital in the creation of human capital. American Journal of Sociology, 94(Supplement), 95-120. 
Fitzgerald, B. K., \& Delaney, J. A. (2002). Educational opportunity in America. In D. E. Heller (Ed.), Condition of access: Higher education for lower income students (pp. 3-24). Westport, CT: American Council on Education/Praeger.

Furstenberg, F. F., Cook, T. D., Eccles, J., Elder, G. H., \& Sameroff, A. (1999). Managing to make it: Urban families and adolescent success. Chicago: University of Chicago Press.

Gándara, P. (1995). Over the ivy walls: The educational mobility of low-income Chicanos. Albany: State University of New York Press.

Gándara, P. (2002). Meeting common goals: Linking K-12 and college interventions. In W. G. Tierney \& L. S. Hagedorn (Eds.), Increasing access to college: Extending possibilities for all students (pp. 81-103). Albany: State University of New York Press.

Grodsky, E., \& Jones, M. (2004). Real and imagined barriers to college entry: Perceptions of cost. Paper presented at the annual meeting of the American Education Research Association, San Diego, CA.

Heller, D. E., \& Marin, P. (Eds.) (2004). State merit scholarship programs and racial inequality. Cambridge, MA: Harvard Civil Rights Project.

Hoover-Dempsey, K., \& Sandler, H. M. (1997). Why do parents become involved in their children's education? Review of Educational Research, 67(1), 3-42.

Horn, L. J. (1998). Confronting the odds: Students at risk and the pipeline to higher education (NCES Report No. 98-094). Washington, DC: U.S. Department of Education.

Hossler, D., Schmit, J., \& Vesper, N. (1999). Going to college: How social, economic, and educational factors influence the decisions students make. Baltimore: Johns Hopkins University Press.

Kane, T. J. (1999). The price of admission: Rethinking how Americans pay for college. Washington, DC: Brookings Institution Press.

Lareau, A. (1987). Social class differences in family-school relationships: The importance of cultural capital. Sociology of Education, 60, 73-85.

Lareau, A. (2000). Home advantage: Social class and parental intervention in elementary education (2nd ed.). Lanham, MD: Rowman and Littlefield.

Lee, S. A. (1993). Family structure effects on student outcomes. In B. Schneider \& J. S. Coleman (Eds.), Parents, their children, and school (pp. 43-75). Boulder, CO: Westview Press.

McDonough, P. M. (1997). Choosing colleges: How social class and schools structure opportunity. Albany: State University of New York Press.

Muller, C. (1993). Parent involvement and academic achievement: An analysis of family resources available to the child. In B. Schneider \& J. S. Coleman (Eds.), Parents, their children, and school (pp. 77-113). Boulder, CO: Westview Press.

National Association of State Student Grant and Aid Programs (NASSGAP, 2005). Thirty-fifth annual survey report on state-sponsored student financial aid: 2003-04 academic year. Retrieved February 27, 2006, from www.nassgap.org.

National Center for Public Policy and Higher Education (2006). Measuring up 2006. San Jose, CA: Author. Retrieved March 2, 2007, from www.highereducation.org.

Olivas, M. (2003). State college savings and prepaid tuition plans: A reappraisal and review. Journal of Law and Education, 32, 474.

Perna, L. W. (2000). Differences in the decision to attend college among African Americans, Hispanics, and Whites. Journal of Higher Education, 71, 117-141. 
Perna, L. W. (2004). Impact of student aid program design, operations, and marketing on the formation of family college-going plans and resulting college-going behaviors of potential students. Boston: Education Resources Institute (TERI).

Perna, L. W. (2006). Studying college choice: A proposed conceptual model. In J. C. Smart (Ed.), Higher education: Handbook of theory and research, Volume 20. Dordrecht, The Netherlands: Kluwer.

Perna, L. W., \& Li, C. (2006). College affordability for middle-income students: Implications for college opportunity. Journal of Student Financial Aid, 36(1), 7-24.

Perna, L. W., Rowan-Kenyon, H. T., Bell, A., Anderson, R., Li, C., \& Thomas, S. L. (2008). Increasing access to college: Understanding the role of college counselors. Review of Higher Education, 31, 131-160.

Perna, L.W., \& Titus, M. (2005). The relationship between parental involvement as social capital and college enrollment: An examination of racial/ethnic group differences. Journal of Higher Education, 76, 485-518.

Plank, S. B., \& Jordan, W. J. (2001). Effects of information, guidance, and actions on postsecondary destinations: A study of talent loss. American Educational Research Journal, 38, 947-979.

Stanton-Salazar, R. D. (1997). A social capital framework for understanding the socialization of racial minority children and youth. Harvard Educational Review, 67, 1-40.

Stout, L. (1996). Bridging the class divide and other lessons for grassroots organizing. Boston: Beacon Press.

Tierney, W. G. (2002). Parents and families in precollege preparation: The lack of connection between research and practice. Educational Policy, 16, 588-606.

Tierney, W. G., \& Auerbach, S. (2005). Toward developing an untapped resource: The role of families in college preparation. In W. G. Tierney, Z. Corwin, \& J. E. Colyar (Eds.), Preparing for college: Nine elements of effective outreach. Albany: State University of New York Press.

Warschauer, M. (2004). Technology, academic preparation, and equity: A comparative study (Report No. Pb-007-1004). Los Angeles: University of California All Campus Consortium on Research for Diversity.

Yin, R. K. (2003a). Applications of case study research (2nd ed.). Applied Social Research Methods Series, Volume 34. Thousand Oaks, CA: Sage.

Yin, R. K. (2003b). Case study research: Design and methods (3rd ed.). Applied Social Research Methods Series, Volume 5. Thousand Oaks, CA: Sage.

Zick, C. D., Bryant, W. K., \& Osterbacka, E. (2001). Mothers' employment, parental involvement, and the implications for intermediate child outcomes. Social Science Research, 30, 25-49. 